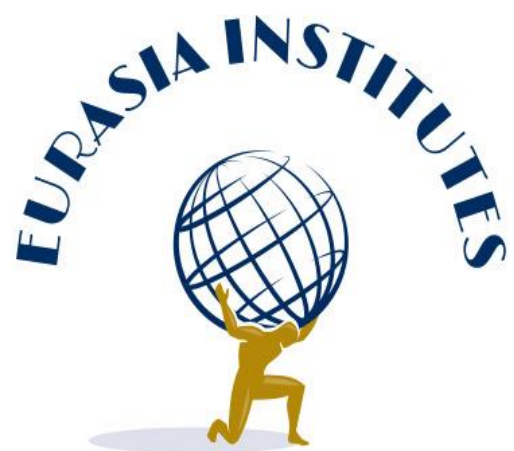

DOI: https://doi.org/10.47669/PSPRP-4-2020

\title{
The State of Human Rights and Political Freedoms in Belarus: Was the Crisis Inevitable?
}

Nina Kolarzik and Aram Terzyan

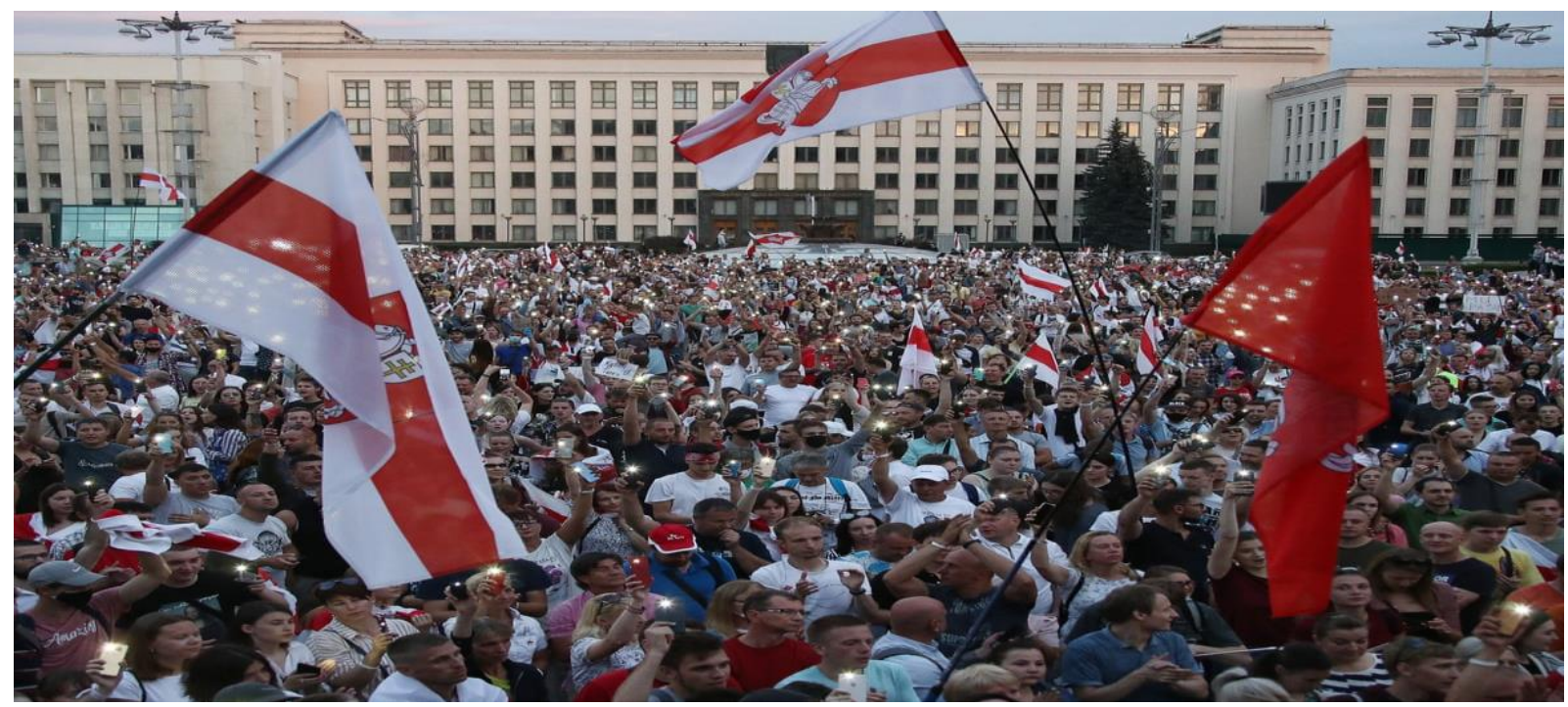

Center for East European and Russian Studies 


\begin{abstract}
The rule of Alexander Lukashenko in Belarus has created one of the most resilient authoritarian regimes in post-communist Europe. Meanwhile, the turmoil triggered by the 2020 presidential election has put in the spotlight the mounting challenges facing Lukashenko's authoritarian rule. This paper investigates the state of human rights and political freedoms in Belarus, focusing on the main rationale behind the turmoil surrounding the 2020 presidential election. It concludes that the political crisis following the elections is the unsurprising consequence of Lukashenko's diminishing ability to maintain power or concentrate political control by preserving elite unity, controlling elections, and/or using force against opponents.
\end{abstract}

Keywords: Belarus, human rights, authoritarian rule, elections, civil society.

\title{
Introduction
}

Situated in the European Union - Russia shared neighborhood, Belarus has been characterized by 'Soviet nostalgia' rather than European aspirations. Politically, Belarus shows more similarities with the republics of post-Soviet Central Asia than with its neighbors in Europe. Since the collapse of the Soviet Union Belarus has gone from being a new and fragile democracy to a pariah state, largely regarded as "the last dictatorship in Europe" (Rudling 2008).

Nevertheless, the anti-government protests following the 2020 presidential election show that despite the administrative, police and propaganda measures the Belarusian opposition and civil society managed to produce a real challenge to the existing status quo.

This paper analyses the state of human rights and political freedoms in Belarus, focusing on the recent events in the country regarding the presidential election in August 2020 and the subsequent protests.

For this purpose, the Universal Declaration of Human Rights (UN 1948) was taken as a basis to first evaluate the general situation in Belarus concerning political rights and civil liberties. Afterwards, the recent protests and the human rights violations during those events will be examined.

The sources are secondary data taken from various non-governmental organisations (NGOs). Their reports are based for example on fieldwork and documented observations, interviews of activists and protesters, news and blog reports from independent journalists or NGOs based in Belarus, foreign media, etc. 


\section{The State of Human Rights, Political Freedoms and Civil Liberties}

The question as to why Belarus gained the reputation of Europe's "last dictatorship" provokes an inquiry into the state political freedoms and human rights across the country.

As a matter of fact, the post-soviet transition of Belarus has been marred by a series of authoritarian malpractices, ranging from centralization and personalization of power to extensive crackdown on civil liberties and political freedoms. Clearly, elections without content are characteristic of electoral authoritarianism.

Elections do exist, but they are neither free nor fair. Freedom House claims that there was never a democratic transfer of power in Belarus (2020a). Since Lukashenko was elected in 1994, he has extended his precedency by unfair means.

The elections in Belarus fall short on the standards of democracy: the media coverage does not inform well to make an independent choice, during the campaign period the freedom of expression and assembly are restricted to make free public statements difficult, the legal framework is restrictive, independent and opposition candidates have difficulties and in the vote counting, irregularities were found. While government loyal candidates won all the seats in the Chamber of Representatives, independent candidates got none of those (Freedom House 2020a). In effect, elections in Belarus fail to meet democratic standards.

Using selective repression - targeting mainly those openly wanting to change the status quo, while allowing some controlled openness for individuals, as long as they refrain from "doing politics" - has long discouraged political activism and contributed to a negative perception of the "opposition" as a noisy sub-group of the population across Belarus (Bedford 2017).

As a result, the political opposition is hindered and pluralism in politics remains limited. The president congregates most of the power. The interests of religious or ethnic minorities are not represented in any of the registered parties. The voters have limited opportunities to make a choice and express their views, engaging in political activism is a risk that can lead amongst others to fines, discrimination in working and educational environments (Freedom House 2020a).

Analysing the key sources of political competition in Belarus, Way (2011) notes that competitive politics has been rooted less in robust civil societies, strong democratic institutions, or leadership than in the inability of incumbents to maintain power or concentrate 
political control by preserving elite unity, controlling elections, and/or using force against opponents. Such "pluralism by default" has been the outgrowth of the strength of antiincumbent national identity and incumbent weakness as defined by a lack of know-how, ineffective incumbent organization, and/or the weakness of certain dimensions of state power (Way 2005).

In effect, while post-communist civil societies are often considered uniformly weak and ineffective, Belarus does not have a functioning civil society. Authentic, pro-democratic non-governmental organizations appear to be small, marginalized and with limited influence inside the country (Matchanka 2014).

The freedom of assembly is very restricted in Belarus, by law as well as through practical measures by the government authorities. Permissions for protests are being denied and websites that call for non-authorised protests banned, while protesters and activists are facing fines, harassment, intimidation, detention and even imprisonment (Freedom House 2020a; Amnesty International 2020 p.6, 10). In January 2019 the law on mass events was changed and introduced new obligations for organisers to be responsible (also financially) for cleaning and policing public events, which is an additional obstacle for protest organisers (Amnesty International 2020, p.10).

This is related to similar restrictions regarding the freedom of association. Public associations and NGO's have difficulties registering: the registration of groups is granted only selective and applications are often denied for arbitrary reasons. Informal and spontaneous initiatives and groups are becoming more popular, but there are large fines for participation in unregistered or liquidated organisations (Civicus Monitor 2020b; Freedom House 2020a; Amnesty International 2020, p.10). Furthermore, independent labour unions experience harassment and their leaders' risk being fired because of participating in peaceful protesting (Freedom House 2020a). As a result, civil society actors are condemned to "operate in a context of obstruction and persecution" (Amnesty International 2020, p.6).

Similarly, there are severe restrictions on the freedom of expression in Belarus. The law on mass media was changed in 2018 , since then online media are under stronger control by the state. The access to and the diversity of information in the media is restricted (Amnesty International 2020 p.10; RSF 2020a). The government in Belarus controls the mainstream media as well as the internet, in legal as well as technical ways (Freedom House 2020a).

As a result, the state has a monopoly on information, along with ample means for surveillance. Journalist work with the expectation to be monitored by the Committee for State 
The State of Human Rights and Political Freedoms in Belarus: Was the Crisis Inevitable?

Security. Independent journalists, in particular critical ones, have become are subject to fines, threats, detention, assaults, police raids and criminal prosecution (Freedom House 2020a, RSF 2020a).

According to Freedom House (2020a), the state security is suspected to use wiretapping for surveillance, therefore even private discussions are limited in their freedom. Academic freedom is equally limited, students and staff are under ideological pressure to not oppose the regime, using the degrees and the profession as leverage (Freedom House 2020a).

That said, the freedom of expression is legally and practically very restricted and government- critical voices must expect severe consequences by the authorities when raising their voices. Similarly, the freedom of movement has been extremely limited, vividly manifested in the arbitrary detentions of opposition activists at border crossings (Freedom House 2020a).

As a matter of fact, the state repression considerably affects the development of women's activism by influencing the number, scope, and capacity of women's nongovernmental organizations. Women are not much present in leadership positions and even though there are some activism groups concerned with gender-based violence, the government does not seem to be giving great weight to this issue (Freedom House 2020a).

In sum, the political system in Belarus lacks transparency and accountability and has little political pluralism and limited participation. The situation is compounded by lack of checks and balances, with the president wielding unlimited power across the country. There is no independent judiciary in Belarus since the courts are subservient to the president. In politically cases, the legal procedures and rights to a fair trial are being violated. Additionally, there is no independent, international body present to police these violations (Freedom House 2020a).

Human rights groups report about cases of physical force and torture next to including arrest or imprisonment used by law enforcement agencies against the suspects (Freedom House 2020a; Amnesty International 2020, p.7).

A fair and transparent rule of law does not exist in Belarus, while the judiciary is marked by arbitrariness and political exertion of influence. The OSCE states that "the legal system of Belarus today can be characterized as based rather on the 'rule by law than the rule of law"” (2020). 
Even though economic freedoms have improved, the state keeps controlling dominant shares of the economy. This specifically applies to large businesses, who can never be safe from interventions, harassment, and pressure from the government (Freedom House 2020a).

There is a high level of corruption, which is not independently investigated. Unemployed people are being discriminated and there are reports of forced labour. Women are lacking employment opportunities, as mentioned above, which leads to their economic vulnerability and exploitation (Freedom House 2020a)

In terms of the state of basic human rights, it is necessary to note that Belarus is the only country in Europe that makes use of the death penalty and executes prisoners, with much secrecy surrounding the procedure (Amnesty International 2020, p.9).

Furthermore, in connection to the Corona crisis, the "government's denial of the COVID-19 pandemic and its blatant disregard for public health safeguards" (Freedom House 2020d) risks the life of people as well as their health and well-being and therefore violates the human rights.

As for minority rights, it is noteworthy that vulnerable minorities in Belarus are poorly protected and they face wide and varied forms of discrimination. More specifically, ethnic Roma and Poles are pressured by the authorities while they simultaneously try to foster the dominance of Russian language (Freedom House 2020a; Amnesty International 2020, p. 12).

Similarly, there is huge societal and legal discrimination against LGBT+ people: samesex marriage is banned (which also violates the human rights $\S 2$ and 16) and attacks against them are rarely investigated and persecuted (Freedom House 2020a; Amnesty International 2020, p.12). As a result of hate crimes, violence, and harassment against the LGBT+ people, it is not uncommon for them to conceal their identity.

The situation is compounded by the absence of anti-discrimination law or any legal mechanism that would protect minority groups from discrimination and ensure equality before the law (Amnesty International 2020, p.5, 11). In effect, the Belarusian dictatorship leads to enhanced conformity resulting in minority discrimination. To a lesser degree this contention applies to religious minority groups, that often experience government-imposed restrictions (Freedom House, 2020a).

In sum, human rights and political freedoms remain severely restricted in Lukashenko's Belarus, with the authorities suppressing dissent and pluralism across the country. 
The State of Human Rights and Political Freedoms in Belarus: Was the Crisis Inevitable?

\section{Elections and Protests in 2020}

The 2020 presidential election put in the spotlight the alarming state of human rights and civil liberties in Belarus. The following report will present the events in a human rights context, structured into what happened prior to, during and after the elections.

\section{Pre-election}

All the sources reported how in the prelude to the elections, the Belarusian government suppressed independent and opposition voices, through intimidation campaigns and restrictions, arrests and detentions (Freedom House 2020b, 2020c; Amnesty International 2020, p.7; Civicus Monitor 2020a; Civicus Monitor 2020b, Civicus Monitor 2020c; HRW 2020b).

Already in May the targeting of challengers started. Presidential candidates were prevented from registering their candidacy in different ways (Amnesty International 2020; HRW 2020b). Most famously, Viktar Babaryka (the main opposition candidate with a record number of signatures for the candidacy) and Siarhei Tsikhanouski (a blogger who wanted to run for president, his wife did this then instead) were arrested preceding the elections (HRW 2020b; Civicus Monitor 2020b). Moreover, people from the opposition candidate team and their signature collectors were arrested. Such politically motivated prosecutions and mass arrests have led to hundred's activists, journalists, peaceful protesters having been arbitrarily arrested, detained, harassed since May (Freedom House 2020b; Freedom House 2020d, Civicus Monitor 2020b; Amnesty International 2020; HRW 2020b).

There are also incidences of removal, deportation and violence against reporters and independent observers that were monitoring the incidences (Freedom House 2020b; Civicus Monitor 2020b; HRW 2020b; RSF 2020b). Female activists were threatened with rape and withdrawal of their parental right, businesses that support protests were closed and the crowdfunding platform MolaMola shut down (Freedom House 2020c).

A variety of and access to media sites and communication and messaging services like Telegram is restricted or has "have been blocked by the information ministry since August on the grounds that they are used to coordinate opposition activities and circulate calls for mass disobedience" (RSF 2020c). There is little diversity in the official information channels.

In addition to all of this, the new regulations since April, that require a preliminary approval needed to hold assemblies and paying for the policing services (see above), create additional obstacles for the protesters and on freedom of assembly (Civicus Monitor 2020b). 


\section{The day of presidential election 09/08/2020}

On the day of the election, the $9^{\text {th }}$ of August 2020, independent observers detained and "aggressively removed from polling stations" (Freedom House 2020b). International organisations like the Council of Europe and the OSCE were not allowed to have observers to monitor the elections. Only organisations like CIS, good-minded towards Belarus, were granted accreditations (Civicus Monitor 2020c).

Journalists and media were tried to be prevented from reporting, independent news sites blocked and generally reporting about the elections restricted (Civicus Monitor 2020a; Civicus Monitor 2020c). Several journalists were attacked and arrested while they were reporting about the persecutions of activists and political opponents, even though they were identifiers of being from the press (Civicus Monitor 2020b). Some journalists disappeared for several hours or days and it required diplomatic intervention for them to be released (Civicus Monitor 2020c).

The internet and social media were disrupted on the election day (Freedom House 2020b; Civicus Monitor 2020c; RSF 2020c; The Guardian 2020). Irregularities influenced information campaigns and other factors can be summed up as "violation of standards under the OSCE which undermined conditions for free and fair elections" (Civicus Monitor 2020c). The standards of fair and free democratic elections were not fulfilled. The Belarusian Helsinki Committee as well as the Human Rights Centre "Viasna" had observer missions and reported: “"The 2020 presidential election was held in an unprecedented atmosphere of fear and intimidation of society, against the backdrop of repression, which began almost immediately after the announcement of the election and marred every electoral phase."” (Civicus Monitor 2020c).

Following the official announcement about Lukashenko's victory, nationwide protests emerged and tens of thousands took the streets against the result and the whole procedure of the election (Freedom House 2020b). These protests are still ongoing.

\section{The aftermath of elections}

The peaceful protests were met by the government authorities with violence, which is still ongoing today.

Thousands of arrests of people, activists, journalists etc. have taken place up to today (Amnesty International 2020 p.8; Freedom House 2020c; Civicus Monitor 2020c; HRW 2020a). 
The State of Human Rights and Political Freedoms in Belarus: Was the Crisis Inevitable?

Violence is used against the protesters, bystanders, and journalists. Reporters tell about the use of stun grenades, tear gas, rubber bullets and water cannons, that have caused serious injuries (Freedom House 2020b; Civicus Monitor 2020a; Civicus Monitor 2020c).

In the detention centres, people had to experience torture, ill-treatment, and sexual violence (Amnesty International 2020 p.8). Many reports by victims of different physically violent abuses and injuries exists, they tell of torture and other forms of ill- treatment (HRW 2020a). They were hold in custody in inhuman, overcrowded, and unhygienic spaces, and some were only freed again because people were arrested faster than there was space for all the detainees (HRW 2020a). Gender-based harassment that targets specifically female activists takes place (Amnesty International 2020 p.8). All of this happens in a systematic way (HRW 2020a) as a method of punishment and intimidation.

"More than 7,000 protesters have been arrested and more than 200 injured as the authorities use flash grenades, rubber bullets and in a few instances live ammunition against the peaceful protesters. Some detainees have reported torture. At least two people have died - one in police custody. "(Civicus Monitor 2020a)

Since the elections, journalists continue to be a target for violence and persecutions by the Belarusian government (RSF 2020b). The rights of journalists and press have been violated in hundreds of cases, including withdrawal of accreditation, beating, detention and arrest, deportation and imprisonment, often on arbitrary reasons (RSF 2020b).

The responsible security forces, meaning the law enforcement agencies and the police, have not been hold accountable and their actions, which violate several human rights, have not been investigated (Amnesty International 2020 p.8; Civicus Monitor 2020a). Paradoxically, peaceful protesters have been accused of the attempt to destabilise Belarus (Civicus Monitor 2020a).

Perceiving the elections as the trigger, the "most egregious crackdown on human rights in Belarus' post-independence history" (Amnesty International 2020 p.4) became visible.

With the above described events, the Belarusian authorities have violated various human rights, in particular the freedom of assembly and association (\$20), freedom of expression and media freedom (19), right to be free from arbitrary arrests or detention (\$9), freedom from torture or inhuman treatment $(\S 5)$, equality before the law $(\S 7)$ and the right for fair trials $(\S 10)$. That is a violation of "many of Belarus' international human rights obligations and commitments, including as a party to the International Covenant on Civil and 
Political Rights (ICCPR) and the UN Convention Against Torture, as well as a participating OSCE state" (HRW 2020a). For this reason, the international community was called for a debate within the United Nations (UN).

\section{UN debate, resolution and beyond}

On the 18th of September 2020, the UN Human Rights Council was holding a debate about the situation in Belarus in their 45th regular session, because of the human rights violations of Belarus. The source for this section is the respective meeting summary (UN 2020a). Various country representatives and NGOs spoke about the above explained situation and problems.

Particularly strong are the statements of the opening speakers. They all highlight that Belarus has been acting against its international obligations and commitments towards human rights:

Nada Al-Nashif, reading out the statement from Michelle Bachelet, the UN High Commissioner for Human Rights, urges Belarus to facilitate investigations and fulfil the obligations they have under the international human rights treaties Belarus submitted to. Anaïs Marin, the Special Rapporteur on human rights situation in Belarus spoke of how the human rights situation in Belarus during the past election cycle had not changed and that this crisis only reveals how deep the problems run. Ekaterina Novikava, a civic activist, said that she does not feel safe in Belarus now and that citizens lives have lost value for the authorities.

Sviatlana Tsikhanouskaya, who was an opposition candidate instead of her husband and has left Belarus after the election results, reminds the audience that

"[t]he adoption of the [Universal Declaration of Human Rights] meant that Belarus had taken an obligation towards the international community to observe and respect human dignity and basic human rights. This also meant that the international community had a right to react in the strongest terms when this obligation was not being met. It was very important to recognize that standing up for democratic principles and human rights was not interfering in internal affairs." (UN 2020a)

The agenda behind these words seems to be aimed at the international community, not Belarus. Tsikhanouskaya wants to show that this is not solely a matter of internal affairs for Belarus, but that it is a concern of human rights for the whole UN and therefore interference in this case is legitimate, considering the brutality used by the government of Belarus.

In contrast to that, Belarus presented itself at the session as a "concerned country" (UN 2020a) and criticised the format of the debate. It is stated that using the human rights 
The State of Human Rights and Political Freedoms in Belarus: Was the Crisis Inevitable?

argument to intervene in the internal affairs of the country is not acceptable. This is a calculated move since it is common critic of the UN to use human rights as a tool for interventions. In this respect, Belarus is partnering with Russia (Freedom House 2020c).

It also contests the reliability of the media and the information that were presented to the UN, stating that they would present "a lopsided picture of reality put forward by the losers of the elections. A minority had not agreed with the results of the elections, which had led to protests that had caused conflicts" (UN 2020a). With that statements the authorities not only hold on to the official result of over 80 percent of the votes being for Lukashenko (Auseyushkin \& Roth 2020), which portraits the opposition as a small group of frustrated people, something that is contested by activists who point to the nationwide protests that show more than a minority opposition. But the government also assigns the guilt for the conflict and the violence to the protesters and away from itself. Many accusations that were denied, or called "unfounded" and "unproven", and the government claims to have been prepared for a peaceful solution, but that the situation did not allow it.

This defence by the country in question however a resolution was adopted in which the

"Council calls upon the Belarusian authorities to enter into a dialogue with the political opposition, including the Coordination Council and civil society, in order to guarantee respect for human rights law, including civil and political rights. The Council urges the Belarusian authorities to fulfil their obligations under international human rights law [...]" (UN Human Rights Council 2020; UN 2020b).

Moreover, the latest report of the OSCE concludes "that the presidential elections of 9 August 2020 have been falsified and that massive and systematic human rights violations have been committed by the Belarusian security forces in response to peaceful demonstrations and protests" (OSCE 2020, p.55). The situation is evaluated as a case of human rights violations and election fraud, with elections that were neither fair nor free (OSCE 2020 p.3). The OSCE summary of human rights violations by international standards lists

“'Intimidation and persecution of political activists, candidates, journalists, media actors, lawyers, labour activists and human rights defenders, as well as the detention of prospective candidates; election fraud; restriction on access to information, including internet shutdowns; excessive use of force against peaceful protesters; arbitrary and 
unlawful arrests or detentions; beatings; sexual and gender violence; abductions and enforced disappearances; torture and other cruel, inhuman or degrading treatment or punishment, and widespread impunity for all of the above. "“ (2020, p.3).

The OSCE made several recommendations to Belarus, the first ones being: "Cancel the results of the presidential elections of 9 August 2020 due to irregularities at all stages of the process" and "Organize new genuine presidential elections based on international standards" (OSCE 2020 p.4). However, considering the previous behavior, a positive reaction by the Belarusian authorities to these recommendations seem at the current stage unlikely.

Not surprisingly, Freedom House scores Belarus as a not free country (2020a), it places $153^{\text {rd }}$ in the world press freedom index (RSF 2020a) while the civic space is rated as "Repressed" (Civicus Monitor 2020a).

\section{Interim conclusion}

The turmoil surrounding the 2020 presidential election in Belarus is the unsurprising consequence of Lukashenko's diminishing ability to maintain power or concentrate political control by preserving elite unity, controlling elections, and using force against opponents.

The crisis per se is the indictment of Belarus' post-soviet political development, marred by a series of authoritarian malpractices, ranging from centralization and personalization of power to extensive crackdown on civil liberties and political freedoms.

The events in Belarus put in the spotlight the scale of human rights violations across the country. The freedoms of peaceful assembly and association, along with those of expression remain severely restricted, compounded by a massive crackdown on opposition activists.

Lukashenko's government keeps feeding the narrative that the reason why the West exerts pressure on Belarus is its close alliance with Russia. Meanwhile, the EU's and USA's emphasis on human rights is treated as a Western imposition aimed at legitimising their interferences in the country's domestic affairs. This narrative has been consistently used to oppose the international demands for respecting human rights, while portraying the opposition as a destabilizing "minority" with anti-state conspiracies.

The ongoing protests however show that considerable part of the population craves for fundamental changes stronger and louder than ever before. It is to be seen how much the civil society can do to challenge Lukashenko's inherently authoritarian rule. 
The State of Human Rights and Political Freedoms in Belarus: Was the Crisis Inevitable?

\section{References}

Amnesty International (2020). "Belarus: Serious Human Rights concerns persist", Amnesty International Submission for UN Universal Periodic Review. Available at: https://www.amnesty.org/download/Documents/EUR4917812020ENGLISH.PDF (Accessed: 10/28/2020).

Auseyushkin, Y. \& Roth, A. (2020). "Belarus election: Lukashenko's claim of landslide victory sparks widespread protests", The Guardian. Available at: https://www.theguardian.com/world/2020/aug/09/belarus-election-lukashenko-landslidevictory-fixing-claims (Accessed: 10/28/2020).

Available at: https://rsf.org/en/news/belarus-rsf-unblocks-three-belarusian-websitescensored-during-protests (Accessed: 10/28/2020).

Available at: https://www.ungeneva.org/en/news-media/meetingsummary/2020/09/human-rights-council-holds-urgent-debate-situation-human-rights (Accessed: 10/28/2020).

Available at: https://www.ungeneva.org/en/news-media/meetingsummary/2020/09/human-rights-council-adopts-resolution-situation-human-rights (Accessed: 10/28/2020).

Bedford, S. (2017). "The Election Game:" Authoritarian Consolidation Processes in Belarus. Demokratizatsiya: The Journal of Post-Soviet Democratization, 25(4), pp. 381-405.

Civicus Monitor (2020a). "Belarus: More than 7000 peaceful protesters arrested and hundreds injured", Statement at the 45th Session of the UN Human Rights Council. Available at: https://www.civicus.org/index.php/media-resources/news/united-nations/geneva/4629belarus-more-than-700-peaceful-protesters-arrested-and-hundreds-injured

(Accessed: $10 / 28 / 2020)$.

Civicus Monitor (2020b). “Opposition candidates and supporters persecuted, detained ahead of elections". Available at: https://monitor.civicus.org/updates/2020/08/11/oppositioncandidates-and-supporters-persecuted-detained-ahead-elections/ (Accessed: 10/28/2020).

Civicus Monitor (2020c). "Mass protests follow disputed election results". Available at: https://monitor.civicus.org/updates/2020/08/20/mass-protests-follow-disputed-electionresults/ (Accessed: 10/28/2020) .

Freedom House (2020a). "Belarus". Available at: https://freedomhouse.org/country/belarus/freedom-world/2020 (Accessed: 10/28/2020). 
Freedom House (2020b). "Belarus: Freedom House Condemns Violence and Election Irregularities". Available at: https://freedomhouse.org/article/belarus-freedom-housecondemns-violence-and-election-irregularities (Accessed: 10/28/2020).

Freedom House (2020c). "Belarus is Ready for Change No Matter What Its President Thinks". Available at: https://freedomhouse.org/article/belarus-ready-change-no-matterwhat-its-president-thinks (Accessed: 10/28/2020).

Freedom House (2020d). "Belarus: Presidential Election Campaign Marred by Repressive Tactics". Available at: https://freedomhouse.org/article/belarus-presidentialelection-campaign-marred-repressive-tactics (Accessed: 10/28/2020).

Human Rights Watch (2020a). "Belarus: Systematic Beating, Torture of Protesters". Available at: https://www.hrw.org/news/2020/09/15/belarus-systematic-beatings-tortureprotesters (Accessed: 10/31/2020).

Human Rights Watch (2020b). "Belarus: Crackdown on Political Activists, Journalists". Available at: https://www.hrw.org/news/2020/07/30/belarus-crackdownpolitical-activists-journalists (Accessed: 10/31/2020).

Matchanka, A. (2014). Substitution of Civil Society in Belarus: Government-Organised Non-Governmental Organisations. Journal of Belarusian Studies, 7(2), pp. 67-94.

OSCE (2020). “OSCE Rapporteur's Report under the Moscow Mechanism on Alleged Human Rights Violations related to the Presidential Elections of 9 August 2020 in Belarus”, OSCE Office for Democratic Institutions and Human Rights, No 358/2020. Available at: https://www.osce.org/files/f/documents/2/b/469539.pdf (Accessed: 13/11/2020).

RSF (2020a). "Belarus”. Available at: https://rsf.org/en/belarus (Accessed: 10/28/2020).

RSF (2020b). "RSF asks UN to condemn Belarus crackdown on journalists, curbs on press freedom". Available at: https://rsf.org/en/news/rsf-asks-un-condemn-belaruscrackdown-journalists-curbs-press-freedom (Accessed: 10/28/2020).

RSF (2020c). "Belarus: RSF unblocks three Belarusian websites censored during protests".

Rudling, P. A. (2008). Belarus in the Lukashenka era: National identity and relations with Russia. In Europe's Last Frontier? (pp. 55-77). Palgrave Macmillan, New York.

UDHR (1948). "Universal Declaration of Human Rights" Available at: https://www.ohchr.org/EN/UDHR/Documents/UDHR_Translations/eng.pdf (Accessed: 10/26/2020). 
The State of Human Rights and Political Freedoms in Belarus: Was the Crisis Inevitable?

UN (2020a) "Human Rights Council holds urgent debate on the situation of human rights in Belarus", Meeting Summary, Available at: https://www.ungeneva.org/en/newsmedia/meeting-summary/2020/09/human-rights-council-holds-urgent-debate-situationhuman-rights (Accessed: 10/31/2020).

UN (2020b) "Human Rights Council adopts resolution on the situation of human rights in Belarus", Meeting Summary, Available at: https://www.ungeneva.org/en/newsmedia/meeting-summary/2020/09/human-rights-council-adopts-resolution-situationhuman-rights (Accessed: 10/31/2020).

UN Human Rights Council (2020) "Human Rights Council adopts resolution on situation of human rights in Belarus". Available at: https://www.ohchr.org/EN/NewsEvents/Pages/DisplayNews.aspx?NewsID=26262\&LangI D=E\#: :text=In\%20the\%20resolution\%20(A\%2FHRC,for\%20human\%20rights\%20law\%2 C\%20including (Accessed: 10/31/2020).

Way, L. A. (2005). Authoritarian state building and the sources of regime competitiveness in the fourth wave: The cases of Belarus, Moldova, Russia, and Ukraine. World Politics, 57(2), pp. 231-261. 